\title{
PERUBAHAN pH SALIVA SEBELUM DAN SESUDAH MENGKONSUMSI MAKANAN KARIOGENIK
}

\author{
Rd. Wianti Soeryani ${ }^{1}$, Aditya Nurrochman ${ }^{1}$, Widi Nurwanti ${ }^{1}$, Syamlailanti Tri Khoirunisa $^{1}$ \\ ${ }^{1}$ Akademi Kesehatan Gigi Ditkesad, Indonesia
}

\begin{tabular}{|c|c|}
\hline Info Artikel & Abstrak \\
\hline $\begin{array}{l}\text { Genesis Naskah: } \\
\text { Submitted: } 2 \text { Oktober } 2020 \\
\text { Revised : } 12 \text { Oktober } 2020 \\
\text { Accepted : } 19 \text { Oktober } 2020\end{array}$ & $\begin{array}{l}\text { Makanan kariogenik seperti coklat dan permen sangat efektif menimbulkan karies gigi karena } \\
\text { akan menyebabkan timbulnya penurunan pH saliva yang akan menyebabkan proses } \\
\text { demineralisasi. Tujuan penelitian ini untuk mendapat perubahan pH saliva sebelum dan sesudah } \\
\text { mengkonsumsi makanan kariogenik pada murid kelas VII B SMP Kuntum Wijaya Kusuma } \\
\text { Jakarta Timur pada tahun 2020. Pengambilan sampel yang digunakan adalah total sampel } \\
\text { dengan penelitian deskriptif. Jumlah sampel sebanyak } 30 \text { siswa SMP Kuntum Wijaya Kusuma, } \\
\text { Kecamatan Ciracas, Kota Jakarta Timur.Hasil uji wilcoxon untuk analisa data konsumsi coklat } \\
\text { didapatkan nilai Asymp. Sig (2-tailed) adalah 0.001, sedangkan untuk analisa data konsumsi } \\
\text { permen Asymp. Sig (2-tailed) adalah 0.001 yang berarti p<0.05 maka hasil penelitian menurut } \\
\text { statistik sangat bermakna. Kesimpulan pada penelitian ini terdapat perubahan antara pH saliva } \\
\text { sebelum dan sesudah mengkonsumsi makanan kariogenik. }\end{array}$ \\
\hline
\end{tabular}

\section{CHANGES IN pH SALIVA BEFORE AND AFTER COMSUMING CARIOGENIC FOOD}

\begin{tabular}{|c|c|}
\hline Keywords: & Abstract \\
\hline Salivary $p H$ and & Cariogenic foods such as chocolate and candy arevery effective in causing dental caries because \\
\hline Kariogenic food & $\begin{array}{l}\text { they will cause a decrease in salivary pH which will cause the demineralization process. The } \\
\text { purpose of this study was to obtain changes in salivary pH before and after consuming } \\
\text { cariogenic food in grade VII B students at Kuntum Wijaya Kusuma East Jakarta in 2020. The } \\
\text { sampling used was total sampling with descriptive research. The number of samples were } 30 \\
\text { students of Kuntum Wijaya Kusuma Junior High School, Ciracas sub-district, East Jakarta } \\
\text { City. Wilcoxon test result for the analysis of consuming chocolate data obtained Asymp value. } \\
\text { Sig (2-tailed) is } 0.001 \text {, while for consuming candy data analysis, the value of Asymp is obtained. } \\
\text { Sig (2-tailed) is } 0.001 \text { the mean of }<0.05 \text { then the result of research according to statistics is } \\
\text { very meaningful. The conclusion of this research is that there is a change between the pH of } \\
\text { saliva before and after consuming cariogenic food. }\end{array}$ \\
\hline
\end{tabular}

Korespondensi Penulis:

Rd. Wianti Soeryani

Jl. Abdul Rahman Saleh No. 18 Jakarta Pusat, Indonesia

Email: yanthiesoeryono999@gmail.com

(C) Jurusan Keperawatan Gigi Poltekkes Kemenkes Jakarta I Jl. Wijaya Kusuma No. 47-48 Cilandak Jakarta Selatan, Indonesia email: jdht@poltekkesjakarta1.ac.id 


\section{Pendahuluan}

Karies gigi adalah penyakit jarigan gigi yang ditandai dengan kerusakan jaringan, dimulai dari permukaan gigi dan meluas ke arah pulpa (Tarigan, 2013). Kelompok rentan terhadap karies gigi diantaranya; prasekolah, anak sekolah, ibu hamil dan lansia (Kemenkes RI cit. Ngatemi, 2020).

Berdasarkan hasil Riset Kesehatan Dasar (RISKESDAS) tahun 2018, prevalensi masalah kesehatan gigi dan mulut sebesar $57,6 \%$ dari total penduduk Indonesia dan hanya sebanyak $10,2 \%$ yang mendapat pelayanan dari tenaga medis, terjadinya peningkatan prevalensi karies gigi di Indonesia yaitu pada penderita karies gigi aktif meningkat sebesar $9,8 \%$, dari $43,4 \%$ pada tahun 2007 dan menjadi 53,2\% pada tahun 2013 dari jumlah populasi yang ada di Indonesia.

Faktor yang menjadi resiko terjadinya karies gigi adalah saliva atau air ludah. Saliva adalah cairan sekresi eksokrin di dalam mulut yang berkontak dengan mukosa dan gigi, berasal dari dua pasang kelenjar saliva mayor dan kelenjar saliva minor pada mukosa oral (Kasuma, 2015). Saliva dapat di ukur tingkat keasamannya melalui satuan $\mathrm{pH}$ (Power of Hydrogen). Nilai normal $\mathrm{pH}$ saliva adalah 6,7 sampai 7,4 nilai $\mathrm{pH}$ saliva akan berubah setelah mengkonsumsi makanan (Savira, dkk., 2017).

Coklat danpermen sering disebut sebagai penyebab karies karena makanan tersebut memiliki rasa manis yang berasal dari gula yang merupakan salah satu substrat karbohidrat yang menyebabkan karies (Savira, dkk., 2017). Peningkatan frekuensi konsumsi makanan kariogenik akan menyebabkan keberadaan $\mathrm{pH}$ yang rendah di dalam mulut sehingga terjadi peningkatan demineralisasi dan penurunan remineralisasi (Arisman dalam Rosidi, 2013).

Berdasarkan penelitian Yasmin (2018), menunjukkan bahwa terdapat penurunan nilai $\mathrm{pH}$ saliva pada subyek penelitian yang mengkonsumsi permen dengan rata-rata perubahan 1,2 dari 6,9 menjadi 5,7 sedangkan yang mengkonsumsi coklat mengalami perubahan dengan rata-rata 1,7 dari 6,9 menjadi 5,2 yang menyebabkan kondisi oral menjadi lebih asam. Kondisi ini yang membuat resiko terjadinya karies lebih meningkat.

Penurunan $\mathrm{pH}$ saliva yang menyebabkan kondisi rongga mulut menjadi asam dapat meningkatkan resiko karies gigi yang tinggi (Hidayati, 2015). Penurunan $\mathrm{pH}$ saliva dapat memudahkan pertumbuhan bakteri seperti Streptococcus mutans dan Lactobacillus yang akan mengakibatkan demineralisasi permukaan gigi sehingga dapat terjadi proses pembentukan karies gigi (Putri, 2010). Penurunan $\mathrm{pH}$ saliva yang berulang-ulang dalam jangka waktu tertentu akan mengakibatkan demineralisasi permukaan gigi secara perlahan-lahan, jika hal ini terus dibiarkan maka dapat mengakibatkan lubang pada gigi terus membesar (Mardiati, 2017).

\section{Metode}

Penelitian ini menggunakan penelitian deskriptif, yakni menggambarkan perubahan $\mathrm{pH}$ saliva pada murid kelas VII B di SMP Kuntum Wijaya Kusuma Jakarta Timur. Populasi dalam penelitian ini adalah siswa kelas VII B terdiri dari 37 murid. Pengambilan sampel dilakukan dengan metode total sampling, akan tetapi sampel yang telah memenuhi kriteria inklusi dan telah mengisi informed consent, hingga didapat jumlah sampel sebanyak 30 murid.

Pelaksanaan pemeriksaan $\mathrm{pH}$ saliva, sebelum pengambilan data murid-murid diberikan pejelasan mengenai kegiatan yang dilakukan yaitu akan dilakukan pemeriksaan $\mathrm{pH}$ saliva sebelum dan sesudah mengkonsumsi makanan kariogenik, jenis yang digunakan dalam penelitian ini adalah coklat susu dan permen kembang gula. Murid-murid diinstruksikan untuk mengeluarkan saliva ke dalam cup untuk mengukur $\mathrm{pH}$ sebelum mengkonsumsi makanan kariogenik. Hasil pemeriksaan dicatat pada lembar pemeriksaan $\mathrm{pH}$ saliva.

Murid yang sudah diberikan permen dan coklat masing-masing diinstruksikan untuk mengkonsumsi makanan tersebut selama 1 menit, setelah 5 menit berikutnya, murid-murid diinstruksikan untuk mengeluarkan saliva ke dalam cup, $\mathrm{pH}$ saliva murid diperiksa kembalidan mengukur skornya menggunakan $\mathrm{pH}$ meter. Hasil pemeriksaan dicatat pada lembar pemeriksaan $\mathrm{pH}$ saliva.Data yang diperoleh dibuat diagram serta dianalisis menggunakan SPSS, dengan uji normalitas, uji korelasi, dan perubahan $\mathrm{pH}$ saliva diketahui menggunakan uji wilcoxon.

\section{Hasil}

Diagram 1.Perubahan $\mathrm{pH}$ Saliva Sebelum dan Sesudah MengkonsumsiCoklat dan Permen

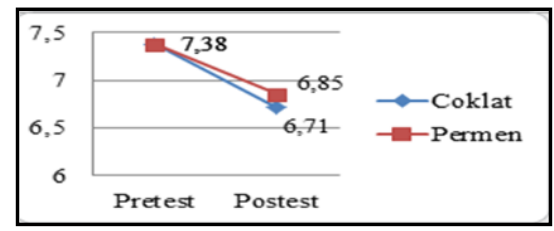


pH saliva mengalami perubahan antara pretest dan postest mengkonsumsi permen dan coklat. Hasil pretest mengkosumsi permen dan coklat rata-rata nilai $\mathrm{pH}$ saliva adalah 7,38. Hasil postest mengkonsumsi permen rata-rata nilai $\mathrm{pH}$ saliva adalah 6,85 , sedangkan hasil postest mengkonsumsi coklat rata-rata nilai $\mathrm{pH}$ saliva adalah 6,71. Selisih perubahan rata-rata nilai $\mathrm{pH}$ konsumsi permen adalah 0,53 , sedangkan selisih perubahan rata-rata nilai $\mathrm{pH}$ saliva konsumsi coklat adalah 0,67.

\section{Tabel 1. Hasil Uji Wilcoxon Konsumsi Coklat}

\begin{tabular}{ccc}
\hline \multirow{2}{*}{ Variabel } & \multicolumn{2}{c}{ Wilcoxon } \\
\cline { 2 - 3 } & $\mathrm{Z}$ & $\mathrm{P}$ \\
\hline Konsumsi Coklat & -3.413 & 0.001 \\
\hline
\end{tabular}

Berdasarkan tabel 1 diatas menunjukkan bahwa ada pengaruh yang signifikan, hal ini ditunjukan dengan $0.001<0.05$ yang berarti $\mathrm{Ho}$ ditolak dan Ha diterima.

\section{Tabel 2. Hasil Uji Wilcoxon Konsumsi Permen}

\begin{tabular}{ccc}
\hline \multirow{2}{*}{ Variabel } & \multicolumn{2}{c}{ Wilcoxon } \\
\cline { 2 - 3 } & $\mathrm{Z}$ & $\mathrm{P}$ \\
\hline Konsumsi Permen & -3.414 & 0.001 \\
\hline
\end{tabular}

Berdasarkan tabel 2 diatas menunjukkan bahwa ada pengaruh yang signifikan, hal ini ditunjukan dengan $0.001<0.05$ yang berarti Ho ditolak dan Ha diterima.

\section{Pembahasan}

Hasil penelitian tentang gambaran perubahan $\mathrm{pH}$ saliva sebelum dan sesudah mengkonsumsi makanan kariogenik pada siswa kelas VII SMP Kuntum Wijaya Kusuma, Kecamatan Ciracas, Kota Jakarta Timur Tahun 2020 yang telah dilakukan menunjukkan bahwapH saliva mengalami perubahan antara pretest dan postest mengkonsumsi permen dan coklat. Hasil pretest mengkosumsi permen dan coklat rata-rata nilai $\mathrm{pH}$ saliva adalah 7,38 . Hasil postest mengkonsumsi permen rata-rata nilai $\mathrm{pH}$ saliva adalah 6,85, sedangkan hasil postest mengkonsumsi coklat rata-rata nilai $\mathrm{pH}$ saliva adalah 6,71. Selisih perubahan rata-rata nilai $\mathrm{pH}$ konsumsi permen adalah 0,53 , sedangkan selisih perubahan rata-rata nilai $\mathrm{pH}$ saliva konsumsi coklat adalah 0,67.

(C) Jurusan Keperawatan Gigi Poltekkes Kemenkes Jakarta I Jl. Wijaya Kusuma No. 47-48 Cilandak Jakarta Selatan, Indonesia email: jdht@poltekkesjakarta1.ac.id
Coklat termasuk jenis makanan manis dan lengket serta lebih lunak dibandingkan dengan permen, kue, roti, snack. Faktor yang mempengaruhi gerakan mastikasi salah satunya yaitu konsistensi makanan, saat mengkonsumsi makanan dengan konsistensi yang lunak, organ mastikasi kurang menjalankan fungsi pengunyahan(Hidayat, 2014).

Kekuatan mastikasi dapat mempengaruhi saliva yang dihasilkan, karena semakin besar kekuatan mastikasi maka semakin sedikit saliva yang dihasilkan yang dapat menurunkan kapasitas buffer saliva. Hal ini dapat menyebabkan penurunan $\mathrm{pH}$ saliva yang cukup besar (Hidayat, 2014).

Jenis kelamin tidak berpengaruh pada kadar urea saliva yaitu komponen organik yang dapat meningkatkan kapasitas buffer saliva dalam hal ini yang dapat mempengaruhi nilai $\mathrm{pH}$ saliva (Vesthi, 2015), akan tetapi pola hormonal perempuan dapat mempengaruhi penurunan dari sekresi saliva yang juga dapat berpengaruh pada $\mathrm{pH}$ saliva (Yulia, 2017).

Penurunan nilai $\mathrm{pH}$ saliva dipengaruhi oleh kadar lemak yang terkandung pada coklat, karena kandungan lemak pada coklat lebih banyakdibandingkan dengan permen. Kandungan lemak tersebut yang membuat coklat lebih lengket dibanding permen (Savira, 2017).

Penelitian ini apabila dibandingkan dengan penelitian Yasmin (2018) di SDN Parung Bingung, Depok, didapatkan hasil selisih perubahan nilai $\mathrm{pH}$ saliva yang berbeda dimana didapatkan adanya perubahan $\mathrm{pH}$ saliva senilai 1,2 setelah mengkonsumi permen dan adanya perubahan $\mathrm{pH}$ saliva senilai 1,7 setelah mengkonsumsi coklat.

\section{Kesimpulan}

pH saliva mengalami perubahan pada semua murid apabila dibandingkan antara $\mathrm{pH}$ saliva sebelum dan sesudah mengkonsumsi coklat maupun permen, yaitu $\mathrm{pH}$ saliva menjadi lebih asam atau mengala

\section{Saran}

Saran yang dapat diberikan adalah mengurangi konsumsi makanan kariogenik atau makanan yang manis dan melekat karena $\mathrm{pH}$ saliva dapat menurun meskipun kecil dan hal ini dapat menyebabkan lubang gigi seiring dengan berjalannya waktu, akan tetapi apabila sudah mengkosumsi makanan yang manis dan melekat sebaiknya membiasakan diri untuk langsung minum air putih dan berkumur.

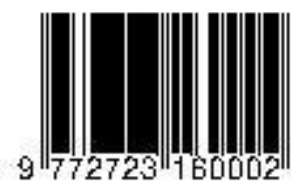




\section{Daftar Pustaka}

Mardiati E, Prasko. (2017). Perbedaan Perubahan pH Saliva antara Berkumur Teh Celup dan Teh Tubruk pada Ibu PKK Kelurahan Muktiharjo Kidul. Jurnal Kesehatan Gigi. Vol 4. No 2.

Hidayat S, Adhani R, Arya IW.(2014). Perbedaan pH saliva menggosok gigi sebelum dan sesudah mengkonsumsi makanan manis dan lengket. Dentino Jurnal Kedoktera Gigi. Vol 2. No 1.

Kasuma N.(2015). Fisiologi dan patologi saliva, Padang: Andalas University Press.

Kementerian Kesehatan Republik Indonesia. (2018). Riset Kesehatan Dasar. Badan Penelitian dan Pengembangan, Jakarta.

Ngatemi, Kristianti J, Widiyastuti R, Insani RL.(2020). Riwayat Pemberian Susu Formula dengan Indek def-t pada Anak Usia Dini di TK Pertiwi IV Pondok Labu Tahun 2020. Journal of Dental Hygiene and Therapy. Vol 1. No1.

Putri MH, Julianti E, Nurjannah N.(2010). Ilmu Pencegahan Penyakit Jaringan Keras dan Jaringan Pendukung Gigi. EGC, Jakarta.

Rosidi A, Haryani S, Adimayanti E.(2013). Hubungan antara konsumsi makanan kariogenik dengan kejadian karies gigi pada anak SD 1 Gogodalem. Prosiding Seminar Nasional. Akper Ngudi Waluyo Ungaran.

Savira CN, Hakim RF, Sungkar S.(2017). Perbedaan $\mathrm{pH}$ saliva sebelum dan sesudah mengkonsumsi susu formula dengan susu UHT. Journal Caninus Dentistry. Vol 2. No 4.

Tarigan R. (2013). Karies Gigi.EGC, Jakarta.

Vesthi NA, Aditya G, Amalina R.(2015). Hubungan Kadar Urea Saliva terhadap Derajat Keasaman (pH) Saliva pada Anak Usia 1215 Tahun. Odonto Dental Jurnal. Vol 2. No 2.

Yasmin I.(2018). Gambaran Perubahan pH Saliva Sebelum dan Sesudah Mengkosumsi Permen dan Coklat pada Murid Kelas IV SDN Parung Bingung Depok.Karya Tulis Ilmiah. Politeknik Kesehatan Kemenkes Jakarta I.

Yulia N, Andayani R, Nasution AI. (2017). Perubahan Laju Aliran Saliva Sebelum dan Sesudah Berkumur Rebusan Jahe Merah pada Mahasiswa FKG Unsyiah Angkatan 2016. Jurnal Caninus Dentistry. Vol 2. No 5. 